\title{
How intrauterine growth restriction due to nutritional stress changes the function of key proteins in brain serotonin metabolism during development
}

\author{
Jorge Hernández-Rodríguez ${ }^{1,2}$, Graciela Chagoya-Guzmán²†, José A. Mondragón-Herrera ${ }^{3}$, \\ Alfonso Boyzo-Montes de Oca², Rosalío Mercado-Camargo ${ }^{4}$, and Gabriel Manjarrez-Gutiérrez ${ }^{3,5 *}$
}

${ }^{1}$ Centro de Comunicación Prenatal Querétaro, Querétaro; ${ }^{2}$ Laboratorio de Neurontogenia Experimental, Centro de Investigación y de Estudios Avanzados (CINVESTAV), Instituto Politécnico Nacional, Mexico City; ${ }^{3}$ Unidad de Investigación Biomolecular de Cardiología, Hospital de Cardiología, Centro Médico Nacional Siglo XXI, Instituto Mexicano del Seguro Social (IMSS), Mexico City; ${ }^{4}$ Facultad de Químico Farmacobiología, Universidad Michoacana de San Nicolás de Hidalgo, Michoacán; 5 Unidad de Investigación en Enfermedades Neurológicas, Hospital de Especialidades, Centro Médico Nacional Siglo XXI, IMSS, Mexico City. Mexico

\begin{abstract}
This review aimed to describe and comment on how experimental intrauterine nutritional stress in animals produced some changes in tryptophan-5-hydroxylases (TPH) 1 and 2 in the brain and other key proteins such as plasma albumin, and how the intrauterine nutritional stress could produce long-lasting alterations in serotonin function in the brain of human infants.
\end{abstract}

Keywords: Intrauterine growth restriction. Undernourishment. Serotonin neurons. Tryptophan-5-hydroxylases. Plasma albumin.

Cómo la restricción del crecimiento intrauterino debida al estrés nutricional cambia la función de proteínas clave en el metabolismo de la serotonina cerebral durante el desarrollo

\section{Resumen}

El objetivo de esta revisión es describir y comentar cómo el estrés nutricional intrauterino experimental en animales produjo algunos cambios en las triptófano-5-hidroxilasas 1 y 2 en el cerebro y en otras proteínas clave, como la albúmina plasmática, y de qué manera el estrés nutricional intrauterino podría producir alteraciones duraderas en la función de la serotonina en el cerebro de lactantes.

Palabras clave: Restricción del crecimiento intrauterino. Desnutrición. Neuronas serotoninérgicas. Triptófano-5-hidroxilasas. Albúmina plasmática.

\section{Introduction}

The present work reviews the results from a long-lasting research project on prenatal undernutrition and brain development. For a long time, biomedical researchers have been interested in early developmental negative influences on the brain of mammals, particularly humans, due to secondary prenatal stress or restricted nutrition, acting together or separately to influence different brain processes during the early

\section{Correspondence:}

*Gabriel Manjarrez-Gutiérrez E-mail: gmanjarrezg@gmail.com; willisga@prodigy.net.mx

Date of reception: 21-10-2020 Date of acceptance: 11-02-2021 DOI: 10.24875/BMHIM.20000334
Available online: 16-12-2021 Bol Med Hosp Infant Mex. 2021;78(6):571-583 www.bmhim.com 1665-1146/@ 2021 Hospital Infantil de México Federico Gómez. Published by Permanyer. This is an open access article under the CC BY-NC-ND license (http://creativecommons.org/licenses/by-nc-nd/4.0/). 
development ${ }^{1}$. In addition, the effect of protein-calorie undernutrition has been thought to profoundly affect human brain development ${ }^{2,3}$, given its general appearance worldwide, particularly in regions that continue to confirm the "Malthusian Principle of Population Growth," related to food production inequality ${ }^{4}$.

Early malnutrition affects some general functions of the human brain, but these observations have always been challenging to interpret, particularly regarding the basic mechanisms underlying these effects ${ }^{5}$, such as protein content, number of brain cells, and lipid metabolism. Also, other general unspecific biochemical parameters have been studied, for example, specific brain functions ${ }^{5-11}$.

More recently, Morgane et al. ${ }^{12}$ reported functional alterations of the hippocampus in early protein-deficient undernourished rats, related explicitly to stressful early conditions. Barros et al. (2006) ${ }^{13}$ reported a decrease in dendritic development in early-life stressed rats ${ }^{13}$. Interestingly, Monk et al. (2013) ${ }^{1}$ reported a decrease in DNA, RNA, and mRNA coding for neural and glial structural proteins after maternal prenatal distress in animal models, decreasing neurotransmitter peptides, independently from the nutritional condition ${ }^{1}$.

\section{Serotonin and its function in the brain}

During intrauterine life, increased serotonin production in the fetal brain due to nutritional stress or after the gene knock-out $(\mathrm{KO})$ of the enzyme in charge of serotonin inactivation (MAOA) produces structural changes and delayed development in the somatosensory cortex $\mathrm{S} 1^{14-17}$.

Serotonin (5-HT, 5-hydroxytryptamine) is an amine produced by a group of brainstem neurons. Axons from these neurons innervate various important areas of the central nervous system $(\mathrm{CNS})^{18-22}$. 5- HT has been implicated in regulating brain development before it assumes its role as a neurotransmitter and neuromodulator in the mature brain ${ }^{23-29}$. During the fetal period, $5-\mathrm{HT}$ is involved in neuronal growth and differentiation processes, axogenesis ${ }^{25,27,28}$, maturation of target neurons $^{26}$, the final expression of specific 5-HT receptors $^{30}$, and modulation of its synthesis ${ }^{31}$. As a neurotransmitter, 5-HT controls numerous physiologic functions (food intake, temporal control, sleep patterns, nociception) ${ }^{32-36}$; also, in some psychiatric disorders such as anxiety and depression ${ }^{37}$ in the adult brain. Serotonin functions in the brain are mediated by activating at least 15 different types of receptors that belong to the $G$ protein-coupled superfamily (except for the $5-\mathrm{HT}_{3}$ subtype $)^{23,31,38,39}$.

One relevant fact is that $5-\mathrm{HT}$ is synthesized from an essential nutrient, L-tryptophan (L-Trp), its metabolic precursor. There are two known fractions of plasma L-Trp, one bound to albumin and one free (FFT, free fraction of L-Trp $)^{40}$. FFT crosses the blood-brain barrier (BBB) to the brain ${ }^{41,42}$, where it is hydroxylated by the action of the tryptophan-5-hydroxylase (TPH), decarboxylated, and transformed into $5-\mathrm{HT}^{43}$.

\section{Nutritional stress and intrauterine growth restriction}

As our group has long pointed out, pre-, peri-, and postnatal undernourishment also cause alterations in specific brain systems during the prenatal to postnatal developmental periods, which is the case of the serotonin neurotransmission system. These alterations activate the brain's serotonergic biosynthetic system and metabolic processes, with an elevation of the FFT, $5 \mathrm{HT}$ metabolic precursor.

Furthermore, it has been demonstrated that plasma albumin changes its ability to bind L-Trp ${ }^{44-52}$. FFT crosses from plasma to the brain through the BBB and is taken up by brainstem serotonergic neurons to activate serotonin synthesis ${ }^{41,43,46,49,51,53,54}$. FFT significantly increases in the plasma and the brain of rats with intrauterine growth restriction (IUGR), reaching levels higher than those of normal controls, showing that the activity of TPH, the limiting enzyme system in the brain's serotonin biosynthetic pathway ${ }^{55-58}$, is upregulated in IUGR brains exhibiting significant changes in its kinetics: increased affinity (lower $\mathrm{K}_{\mathrm{m}}$ ) for its substrate, no changes in the $V_{\max }$, and increased activity under phosphorylation conditions. These changes were considered responsible for the chronically increased serotonin synthesis in the brain of IUGR animals secondary to undernourishment ${ }^{59,60}$.

Two TPH isoforms have been described, TPH1 and $\mathrm{TPH} 2^{61}$. According to the authors who described these TPH isoforms, TPH1 is localized only in peripheral tissues, while TPH2 is present, supposedly only in the CNS ${ }^{62-66}$. Thus, alterations produced by IUGR induce an activation of the brain's serotonergic biosynthetic system and its metabolic correlates, with an elevation of the FFT and the plasma albumin's ability to bind L-Trp ${ }^{52}$. These findings suggest that chronic elevation of $5-\mathrm{HT}$ synthesis in the brain of IUGR rats might be due to a significantly higher amount of TPH1 isoform above that of TPH2. This relation is possibly due to 
changes in the molecular regulatory mechanisms of enzyme expression and regulation of its activity, secondary to early nutritional stress during fetal life, with possible mediation of the Pet-1 regulatory molecular system ${ }^{67-69}$.

In contrast, when the undernourished offspring were subjected to a nutritional recovery (NR) regimen during the neonatal period, a satisfactory recovery was demonstrated in their growth curves and FFT and other plasma biochemical markers, which returned to control values $^{70-74}$. Despite this impressive recovery, the whole TPH activity and TPH1 protein levels remained significantly elevated in the animal brainstems, while a significant increase in brain 5-HT levels and its functional activity also prevailed up to adulthood in IUGR rats s0-74. $^{70}$.

As an attempt to integrate our knowledge about the consequences of IUGR on the brain's neurochemistry and functions in rats, this review considered all published results, as well as the results of previous studies in human infants related to the capacity of another essential protein, plasma albumin, to bind to the precursor amino acid L-Trp, which appears to be a critical regulatory system of the brain's serotonin synthesis. In this manner, we attempted to provide more information on the neurometabolic mechanism implicated in the persistently increased synthesis of $5-\mathrm{HT}$ in the brain of IUGR subjects.

\section{Experimental models of intrauterine growth restriction}

The methods considered in this review were taken from published studies $44,45,48-50$. However, it is worth mentioning that an experimental model of gestational protein-calorie deprivation and early ligation of one branch of the uterine artery in rats was used in an attempt to reproduce conditions of protein-calorie malnutrition and placental insufficiency present in humans. These two experimental procedures would mimic the clinical conditions in pregnant women giving birth to IUGR products. These two methods are complementary in their effects: one involves nutritional and endocrine maternal imbalance, while the other would exclude these variables $^{44,45}$. In a previous study, we evaluated the tracing of thalamocortical fibers in the offspring of IUGR rats and controls on postnatal days 1,3 , and 5 . We also evaluated the immunostaining pattern of the serotonin transporter (SERT) and the serotonin receptor $5-\mathrm{HT}_{1 \mathrm{~B}}$ with the specific antibody for each molecule ${ }^{17,75}$.

All experimental procedures performed on animals followed the Care and Use of Experimental Animals guidelines published by the Mexican Ministry of Health (NOM-062-ZOO-1999; August 22, 2001). Additionally, the Research Ethics Committee of the National Scientific Research Committee of the Mexican Institute of Social Security (IMSS, for its Spanish acronym), Mexico City, Mexico, authorized all human and animal research protocols (registry numbers: 2005-785-078; 2006-3604-07; 2006-2605-08; 2007-3604-12; 2014-785-052).

\section{Intrauterine growth restriction in newborns}

All procedures in infant patients, diagnoses, and clinical care were closely followed by experienced specialists $^{76-78}$. The general conditions of how this review was organized for the various studies conducted in human infants can be wholly reviewed in Hernandez et al. ${ }^{45,52}$ and Manjarrez et al. ${ }^{46,47,49,51}$.

For the human segment of the whole project, we include a representative summary of the procedure followed in a case-cohort study in 37 newborns during the first 3 months of postnatal life. At birth, two groups were formed; the first group (IUGR group) included 20 term newborns with the antecedent of IUGR, with bodyweight $<10^{\text {th }}$ percentile of intrauterine growth curves $^{79}$ and with a fetal growth ratio (FGR) of $<0.90^{80}$. The control group comprised 17 newborns with bodyweight between the $10^{\text {th }}$ and the $90^{\text {th }}$ percentiles and an FGR of $>0.90$. Interestingly, at 30 days of age, nine infants of the IUGR group demonstrated a return to normal physical growth; subsequently, these infants formed the nutritionally recovered group (NR group) (Table 1). Free, bound, and total L-Trp were measured in blood micro-samples. These samples were freed of fatty acids and tested under "mole-to-mole" conditions of the sample components of the IUGR, NR, and control groups to assess the binding kinetics of L-Trp to albumin.

\section{Serotonergic activity in the brain}

In animal models, the variables analyzed generally used included the following in each one of the experimental groups: serotonergic activity, L-Trp, TPH whole activity, and 5-HT concentration expressed as mean and standard deviations (SD). Also, the number of TPH1 or TPH2-immunopositive neurons in each age group was determined in six $4 \mu$ m-thick sections, in an area of $83 \mu \mathrm{m}^{2}$ with a 40X objective (Infinity 1-Lumenera camera equipped with a 10X objective, aided with an 
Table 1. Representative clinical data of infants of the various groups

\begin{tabular}{|c|c|c|c|}
\hline & Controls & Intrauterine growth restriction & Nutritionally recovered \\
\hline $\begin{array}{l}\text { Gestational age (weeks) } \\
\text { Ponderal index } \\
\text { Fetal growth ratio }\end{array}$ & $\begin{array}{c}39.5 \pm 0.7 \\
2.38 \pm 0.26 \\
98 \pm 0.09\end{array}$ & $\begin{array}{c}39.1 \pm 1.20 \\
2.10 \pm 0.29^{€} \\
68 \pm 0.05^{€}\end{array}$ & $\begin{array}{l}- \\
- \\
-\end{array}$ \\
\hline $\begin{array}{l}\text { Body weight }(\mathrm{g}) \\
1 \text { day } \\
30 \text { days } \\
90 \text { days }\end{array}$ & $\begin{array}{l}3,165 \pm 326.9 \\
4,093 \pm 322.3 \\
5,703 \pm 438.2\end{array}$ & $\begin{array}{l}2,125 \pm 234.5^{€} \\
3,316 \pm 332.3^{€} \\
4,671 \pm 387.1^{\ddagger}\end{array}$ & $\begin{array}{c}- \\
3,839 \pm 193.9^{\ell} \\
5,571 \pm 333.9^{\ell}\end{array}$ \\
\hline $\begin{array}{l}\text { Body length }(\mathrm{cm}) \\
1 \text { day } \\
30 \text { days } \\
90 \text { days }\end{array}$ & $\begin{array}{l}51.06 \pm 1.0 \\
56.33 \pm 2.9 \\
62.60 \pm 2.4\end{array}$ & $\begin{array}{l}46.63 \pm 1.6^{€} \\
51.06 \pm 1.5^{€} \\
58.38 \pm 1.0^{€}\end{array}$ & $\begin{array}{c}- \\
54.00 \pm 2.9^{€} \\
61.86 \pm 2.1^{€}\end{array}$ \\
\hline $\begin{array}{l}\text { Body mass index } \\
1 \text { day } \\
30 \text { days } \\
90 \text { days }\end{array}$ & $\begin{array}{l}12.15 \pm 1.13 \\
14.23 \pm 1.23 \\
15.36 \pm 1.02\end{array}$ & $\begin{array}{l}9.90 \pm 1.10^{€} \\
12.46 \pm 0.84^{€} \\
12.74 \pm 1.30^{\ddagger}\end{array}$ & $\begin{array}{c}- \\
13.89 \pm 1.02^{¥} \\
15.28 \pm 1.28^{¥}\end{array}$ \\
\hline
\end{tabular}

Data are expressed as mean values \pm standard deviation of 17 controls, 20 intrauterine growth restriction, and nine nutritionally recovered infants.

Body weight (Treatment: $S S=11340, \mathrm{Df}=7, \mathrm{MS}=1610$. Residual $\mathrm{SS}=7320, \mathrm{Df}=76, \mathrm{MS}=96320$ ). Body length $($ Treatment: $\mathrm{SS}=2226, \mathrm{Df}=7, \mathrm{MS}=317.9$

Residual SS $=286.7, \mathrm{Df}=70, \mathrm{MS}=4.096$ ). Body mass index (Treatment: $\mathrm{SS}=292.5, \mathrm{Df}=7, \mathrm{MS}=4178$. Residual $\mathrm{SS}=101.6, \mathrm{Df}=79, \mathrm{MS}=1.286$ ). Differences were

determined by Mann-Whitney U, ANOVA and Tukey's multiple comparison tests.

${ }^{¥} p<0.01,{ }^{€} p<0.001^{52}$

SS, the sum of squares; MS, mean square; Df, degrees of freedom.

Table 2. Representative serotoninergic activity in the brainstem of rat pups of various groups

\begin{tabular}{|c|c|c|c|c|c|c|c|c|c|}
\hline \multirow[t]{2}{*}{$\begin{array}{l}\text { Age } \\
\text { (days) }\end{array}$} & \multicolumn{3}{|c|}{$\begin{array}{c}\text { L-Trp } \\
\text { ( } \mu \mathrm{Mol} / \mathrm{g} \text { wet tissue) }\end{array}$} & \multicolumn{3}{|c|}{$\begin{array}{c}\text { TPH (whole activity) } \\
\text { (nmol 5-HTP/mg protein/h) }\end{array}$} & \multicolumn{3}{|c|}{$\begin{array}{c}\text { 5-HT } \\
\text { (nmol/g wet tissue) }\end{array}$} \\
\hline & C & IUGR & NR & C & IUGR & NR & C & IUGR & NR \\
\hline 1 & $45.50 \pm 0.50$ & $58.70 \pm 0.68^{*}$ & $57.70 \pm 0.68^{*}$ & $0.217 \pm 0.010$ & $0.310 \pm 0.030^{*}$ & $0.308 \pm 0.030^{*}$ & $0.720 \pm 0.070$ & $1.185 \pm 0.019^{*}$ & $1.067 \pm 0.010^{*}$ \\
\hline 15 & $12.70 \pm 0.28$ & $21.30 \pm 0.21^{*}$ & $13.60 \pm 0.10$ & $0.337 \pm 0.050$ & $0.510 \pm 0.030^{*}$ & $0.512 \pm 0.030^{*}$ & $1.670 \pm 0.050$ & $2.370 \pm 0.031^{*}$ & $2.400 \pm 0.010^{*}$ \\
\hline 21 & $12.70 \pm 0.28$ & $22.30 \pm 0.20^{*}$ & $11.60 \pm 0.20$ & $0.376 \pm 0.030$ & $0.500 \pm 0.010^{*}$ & $0.517 \pm 0.010^{*}$ & $1.840 \pm 0.040$ & $2.750 \pm 0.070^{*}$ & $2.180 \pm 0.060^{*}$ \\
\hline
\end{tabular}

Each point corresponds to mean values \pm standard deviation of six experiments in duplicate.

Differences were determined by two-way ANOVA and post-hoc analysis conducted using the Tukey test.

${ }^{*} p<0.05$ (C vs IUGR; IUGR vs NR; $C$ vs NR). Days = Days after birth ${ }^{70,74,87}$

C, controls; IUGR, in-utero undernourished; NR, nutritionally recovered; L-Trp, L-tryptophan; TPH, tryptophan-5-hydroxylase whole activity; 5-HT, 5-hydroxytryptamine.

Olympus microscope). The relative densities of the bands observed in the dorsal raphe nucleus (DRN) (ages 1, 15, and 21 days) were determined. Afterward, the groups were compared by two-way ANOVA (nursing time 1,15 , and 21 days, and maternal nutritional status in control and undernourished groups), and post hoc analyses using the Tukey comparison test were conducted; $p$-values $<0.05$ were considered statistically significant.

In general, these findings confirmed previous results, showing that malnourished offspring showed higher L-Trp concentration, 5-HT content, and TPH whole activity in the brainstem. In contrast, L-Trp concentration in the brain returned to normal values in the NR groups. Regardless of their physical and biochemical recovery, TPH whole activity remained significantly elevated, accompanied by an increased synthesis of $5-\mathrm{HT}$ up to the end of lactation and even during adulthood (Table 2).

The identification of TPH1 and TPH2 in the brainstem from the different groups was obtained by Western Blot (Figure $1 \mathrm{~A}$ and $1 \mathrm{~B}$ ). The expression of TPH1 remained increased in the IUGR group from birth, and TPH2 expression predominated and subsequently showed a significant decrease during the lactation period in controls. Interestingly, TPH1 expression remained increased, while TPH2 returned to normal values in the NR group. 


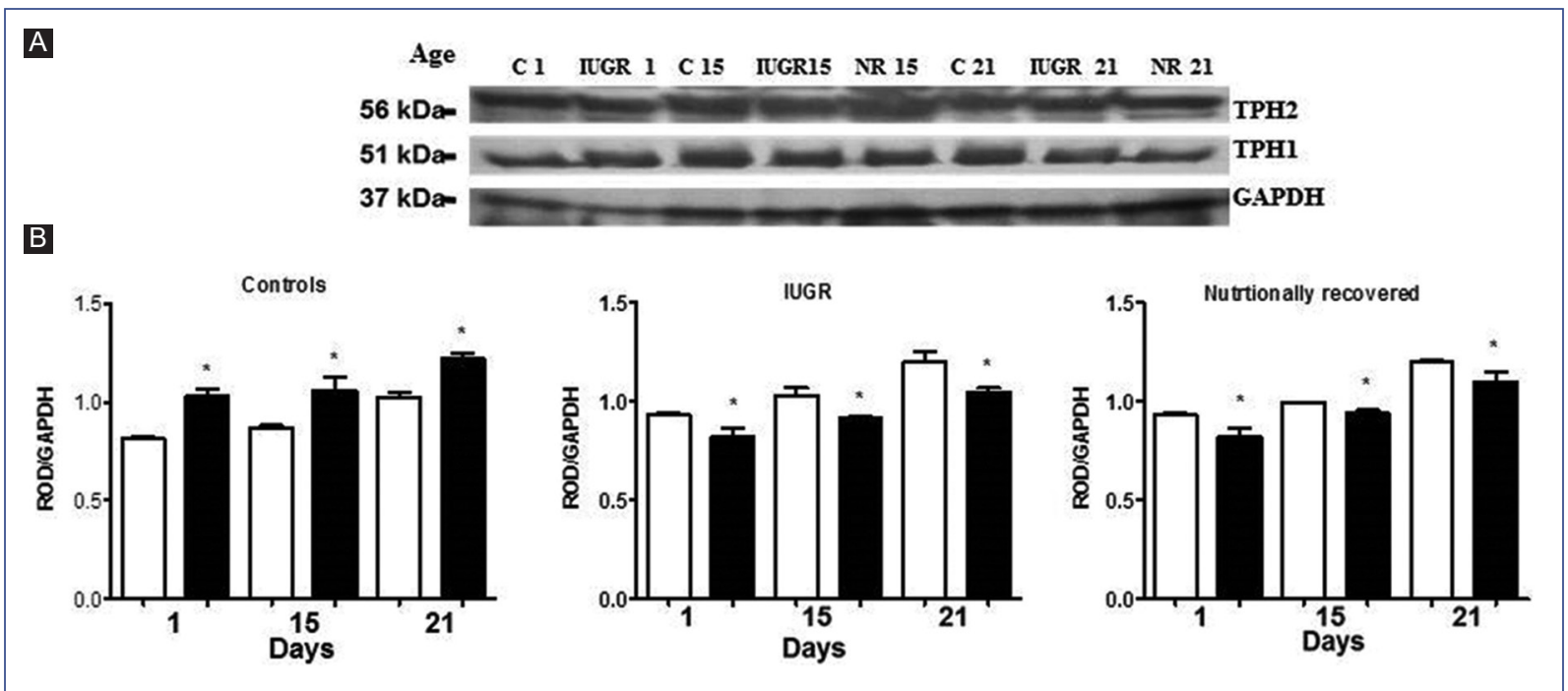

Figure 1. Identification of tryptophan-5-hydroxylases 1 and 2 (TPH1 and TPH2) in the brainstem of the offspring by electro-transference with specific antibodies to each isoform. A. Three bands were observed, one of $51 \mathrm{kDa}$ (TPH1), another of $56 \mathrm{kDa}$ (TPH2), and another of $37 \mathrm{kDa}$ (GAPDH). B. Relative optical density (ROD) of each isoform; 口: TPH1 y $\mathbf{\square}: \mathrm{TPH} 2$.

Each bar corresponds to mean values of ROD \pm standard deviation of six experiments in duplicate of each isoform. ${ }^{*} p<0.05$. (C vs IUGR; IUGR vs NR; C vs NR).

A two-way ANOVA and post-hoc Tukey test analysis were conducted.

C, controls; Days, days after birth ${ }^{87}$; GAPDH, glyceraldehyde-3-phosphate dehydrogenase; IUGR, intrauterine growth restriction; NR, nutritionally recovered.

A population of $5-\mathrm{HT}$ neurons from the DRN was immunolabeled for TPH1 and another for TPH2 (Figure 2 and 3). Interestingly, the IUGR group showed fewer 5-HT immune-positive neurons (TPH1 and TPH2) than controls during the nursing period. It is essential to highlight that pups of the NR group exhibited a return from a decreased neuronal population to control values (Figure 4). Some morphological differences in the serotoninergic neurons between controls and the IUGR group, including the NR group, were having small neurons with little cytoplasm, small nuclei, and more space between them. In addition, immunolabeled serotoninergic neurons that express TPH1 increased in the IUGR and NR groups. Interestingly, the opposite was noted in neurons that expressed TPH2, in which the immunolabeling was lower than controls.

The study in human infants confirmed that IUGR newborns exhibited a delay in physical growth. Remarkably, when they were fed only with maternal milk from birth, they demonstrated an appropriate recovering that allowed them to reach the growth rate of controls during the nursing period ${ }^{52}$. Also, IUGR infants showed significantly lower plasma albumin levels at birth, restored after 30 days of nutritional recovery. Furthermore, the FFT was significantly elevated in IUGR 3-month-old infants but returned to normal values on day 30 of postnatal life in the NR group. Another remarkable finding was that IUGR infants showed the following kinetic constants of albumin-L-Trp binding: high $\mathrm{K}_{\mathrm{D}}$ and low $\mathrm{B}_{\max }$, both remaining unchanged up to postnatal day 90 , even after $\mathrm{NR}^{52}$.

\section{Discussion}

We reviewed data derived from a long-lasting project confirming that undernourishment-related IUGR induces essential changes in the brain's serotonergic-metabolic pathway during early development and that this pathway is overactivated with a concomitant increase in 5-HT levels and functions.

In the related literature, data describes the importance of early alterations on the brain's serotonergic system in laboratory animals. Haydon et al. (1984)25,81 reported a strong effect on in-situ alterations induced by $5-\mathrm{HT}$ excess. These $5-\mathrm{HT}$ levels altered the axonal growth cone in cultured neurons, significantly inhibiting their growth, hence altering their developmental pattern. Also, early inhibition of the activity of the limiting 


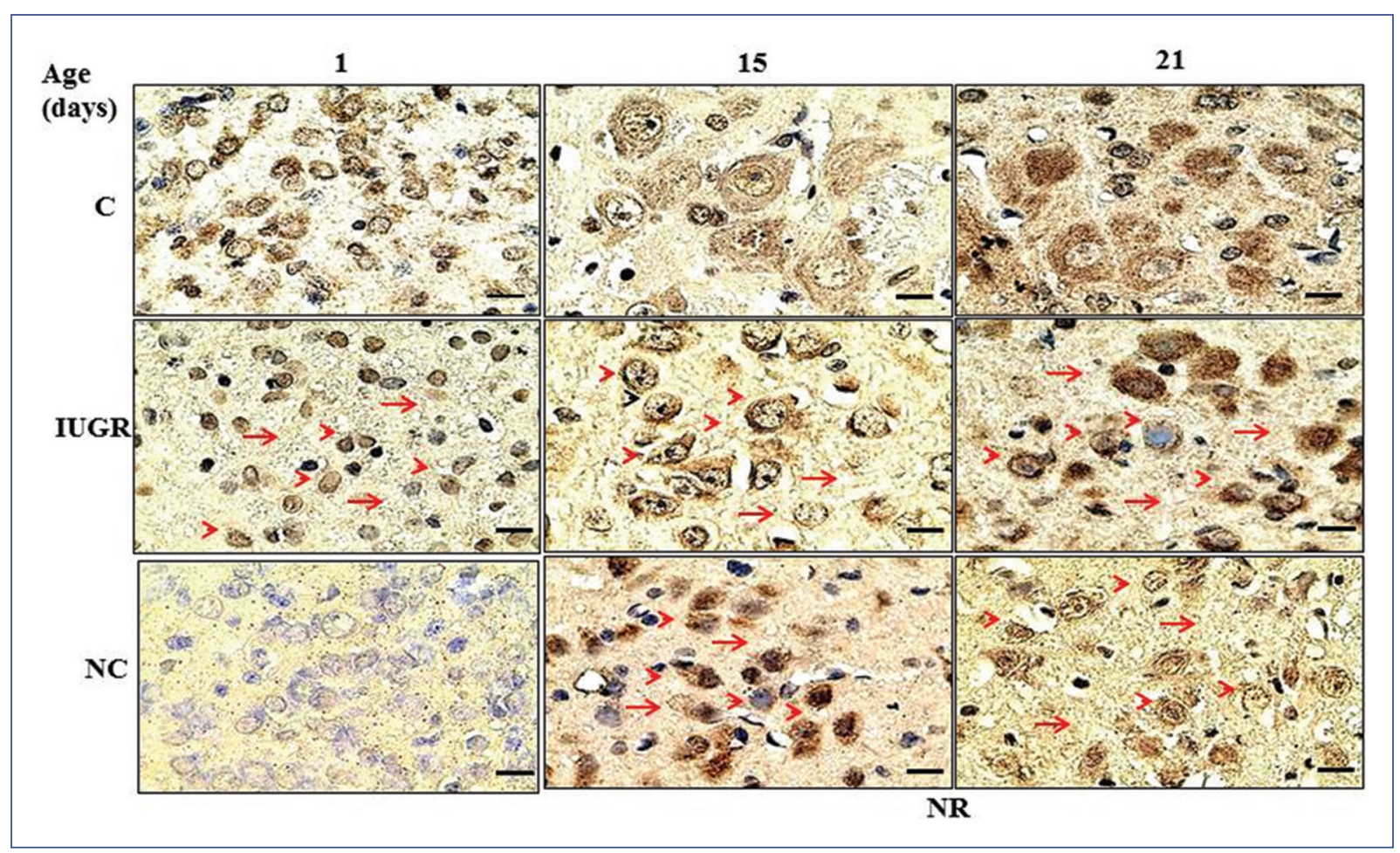

Figure 2. Coronal sections at the level of the DRN show immunoreactive neurons to tryptophan-5-hydroxylase 1. Sections were incubated with enzyme-linked monoclonal antibodies (1:1000), and immunoreactivity was detected with peroxidase-conjugated secondary antibodies and revealed with 3,3-diaminobenzidine on days 1, 15, and 21 after birth ${ }^{87}$. Scale bar in each panel $=100 \mathrm{X}, 4 \mu \mathrm{m}$.

Arrowhead = small neurons with little cytoplasm and small nuclei. Arrow = more space between neurons. C, controls; DRN, dorsal raphe nucleus; IUGR, intrauterine growth restriction; NC, negative control; NR, nutritionally recovered.

enzymes by PCPA ( $P$-chlorophenyl alanine) altered the maturation pattern of neurons innervated by $5-\mathrm{HT}$ in different brain regions ${ }^{82}$. Fillion et al. observed that the early chemical lesion of serotonergic neurons by the intraventricular administration of 5,7-dihydroxytryptamine at birth increased the final number of 5-HT binding sites in rats developing brain ${ }^{30}$. Also, we observed that extra doses of L-Trp to gestational rats increased TPH whole activity, not only in the mother's brain but also in the fetal brain and serotonin synthesis ${ }^{83}$. Other authors have also reported a harmful effect of increasing serotonin levels in the brain during postnatal development ${ }^{84}$. Concerning prenatal brain differentiation, essential participation of 5-HT has been well known for some time in several aspects of this function ${ }^{26}$. For instance, we observed essential functions of $5-\mathrm{HT}$ in the axonal growth cone particles (AGCP) isolated from rat fetal brain of 17 days of gestation ${ }^{27}$. These organelles are mainly responsible for axogenesis and synaptogenesis, among other functions. 5-HT produces serotonin uptake in a $\mathrm{Na}^{+}$-dependent manner, which is subsequently released in a $\mathrm{K}^{+}$and $\mathrm{Ca}^{++}$-dependentmanner in the $A G C P^{27,28}$, supporting the functional role of serotonin in brain neurodifferentiation.

Based on the experimental data published by our group, it is possible to state that fetal neurons have all the necessary elements to produce and use serotonin as follows: a) a regulatory plasma mechanism to obtain the precursor amino acid through FFT kinetic binding to plasma albumin, therefore regulating the amino-acid precursor availability ${ }^{52}$; b) a complete set of molecules to synthesize the neurotransmitter to take it up and release it physiologically; c) a set of specific high-affinity receptors, also identified in axonal growth cones ${ }^{85}$; and d) a molecular signaling cascade that transduces the $5-\mathrm{HT}$ message to the target cells ${ }^{86}$. All these data illustrate how 5-HT works within the fetal brain (Figure 5).

Unexpectedly, the elevated enzymatic activity in IUGR brains appeared to be mainly mediated through 


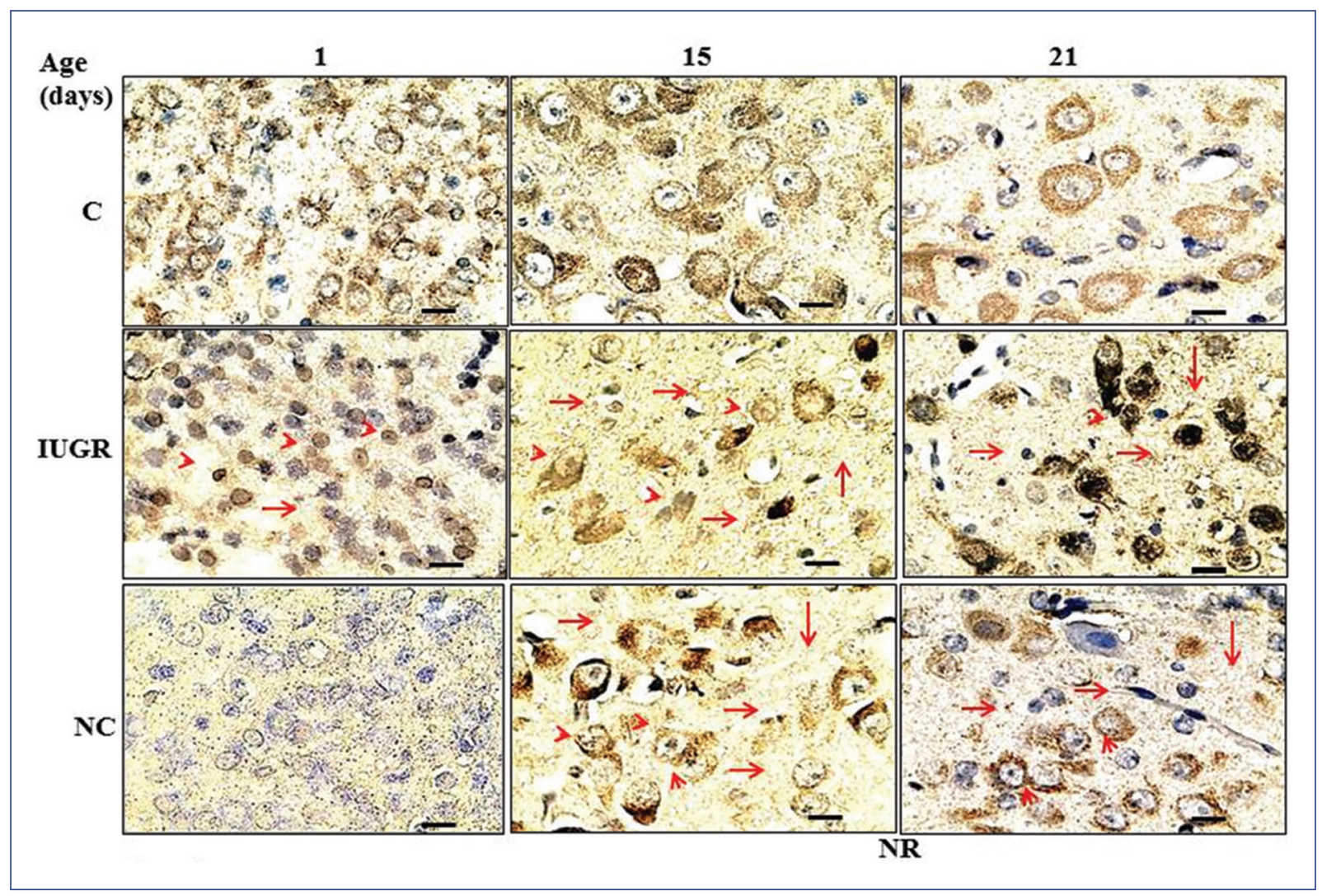

Figure 3. Coronal sections at the level of the DRN show immunoreactive neurons to tryptophan-5-hydroxylase 2. Sections were incubated with enzyme-linked monoclonal antibodies (1:1000), and immunoreactivity was detected with peroxidase-conjugated secondary antibodies and revealed with 3,3-diaminobenzidine on days 1, 15, and 21 after birth. Scale bar in each panel $=100 \mathrm{X}, 4 \mu \mathrm{m}$.

Arrowhead = small neurons with little cytoplasm and small nuclei. Arrow = more space between neurons ${ }^{87}$. C, controls; DRN, dorsal raphe nucleus; IUGR: intrauterine growth restriction; NC, negative control; NR, nutritionally recovered.

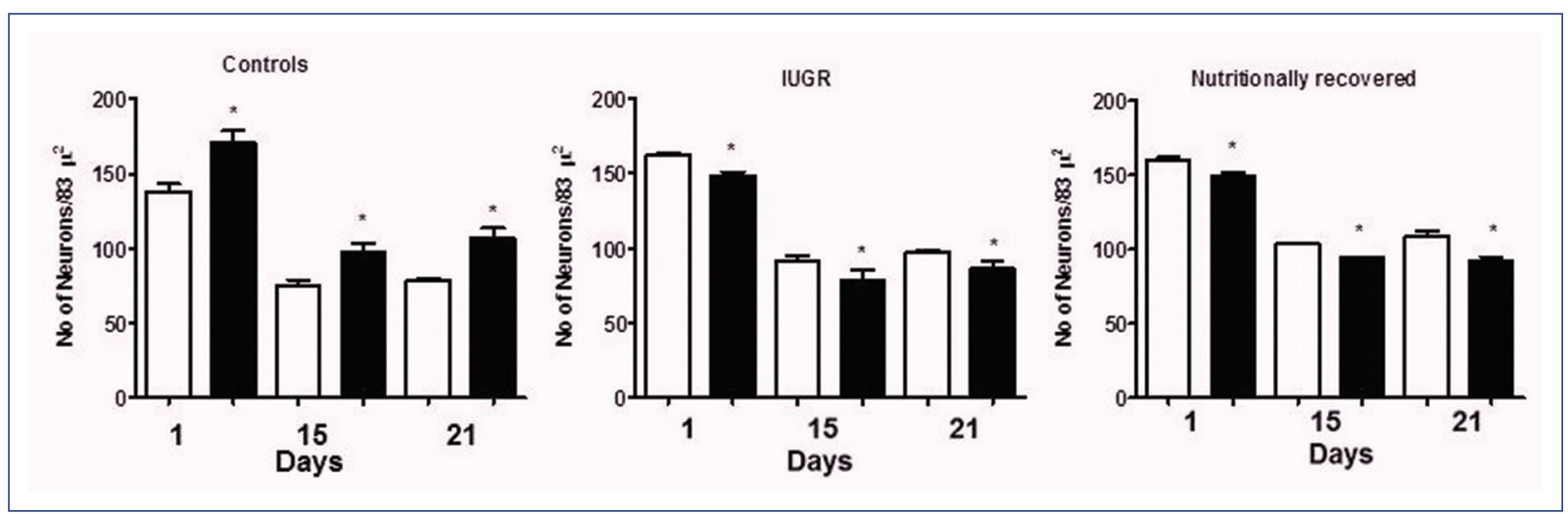

Figure 4. Tryptophan-5-hydroxylase-immunoreactive neurons in the DRN of the offspring. Each bar corresponds to the mean \pm standard deviation of six pups of the groups. $\square$ TPH 1 and $\square$ TPH 2 .

* $p<0.05$. (C vs IUGR; IUGR vs NR; C vs NR).

A two-way ANOVA and post-hoc Tukey test analysis were conducted.

C, controls; Days, days after birth ${ }^{87}$; DRN, dorsal raphe nucleus; IUGR, intrauterine growth restriction; NR, nutritionally recovered. 


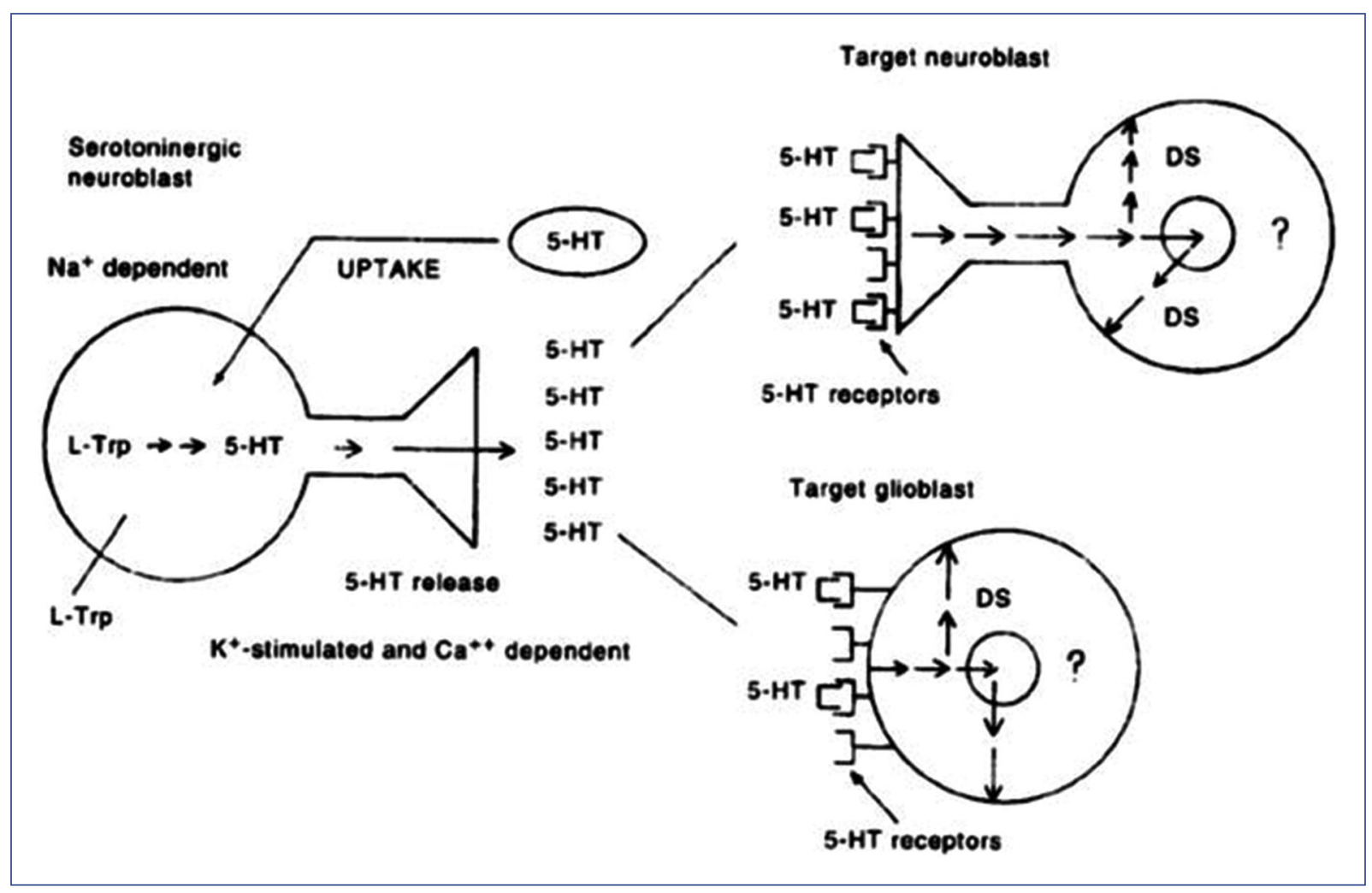

Figure 5. Proposed model of the physiological role of 5 - $\mathrm{HT}$ in the fetal brain. Serotoninergic neuroblasts (left) synthesize and release $5-\mathrm{HT}$ in a $\mathrm{K}^{+}$and $\mathrm{Ca}^{2+}$ dependent way. Target neuroblasts (upper right) or glioblasts (lower right) would have 5 -HT recognizing sites of a specific receptor that receive a differentiation signal whose sequence is unknown (?). 5 -HT could be inactivated by a reuptake system dependent on $\mathrm{Na}^{+}$and fluoxetine.

DS, differentiation signal; 5-HT, 5-hydroxytryptamine ${ }^{65}$.

the activity of TPH1, which was significantly elevated. TPH2 was also present, but its identification by western blot was less evident than TPH1, although still higher than controls, as confirmed later ${ }^{87}$. Therefore, it appears that TPH1 activity in this area of the brain may play an essential role in the overactivation of the brain-serotonin pathway in both IUGR and normal brainstems, which could significantly alter the brain's morphogenetic processes, previously referred to in IUGRmalnourished rats ${ }^{44,45,50,59,60}$. By Western-blot analysis, both TPH isoforms (1 and 2) were expressed in serotonergic neurons in IUGR rats from birth ${ }^{61}$. In this context, it is important to mention that the intensity of the immunolabeling was significantly higher in neurons labeled with the specific anti-TPH1 monoclonal antibody. Interestingly, TPH2 neurons demonstrated a decreased immunopositive intensity at the end of the nursing period compared to the one exhibited by the $\mathrm{TPH} 1$ isoform ${ }^{61}$.
According to the literature, TPH1 expression in the brainstem of IUGR infants or normal eutrophic controls would not be expected because TPH2 predominates in the brain. Thus, the presence and activity of the TPH1isoform in the brain of IUGR and controls require an acceptable explanation. This observation may be due to changes in the TPH regulatory expression exerted by the Pet-1 genetic regulatory system ${ }^{67-69}$. Alternatively, this metabolic modification consisting of the expression of TPH1 activity in the brain-higher than that of TPH2, which was supposed to be the only one active in the brain-could be secondary to hormonal changes due to the early profound stressful conditions exerted by the severe prenatal undernourishment.

Corticoids, other hormones, and nutritional changes may produce a de novo synthesis of enzymatic proteins. For example, it was reported that the genetic system of glucose-6-phosphate dehydrogenase responds to hormonal and dietary manipulations ${ }^{88}$. Thus, the enzymatic changes in the biosynthetic 


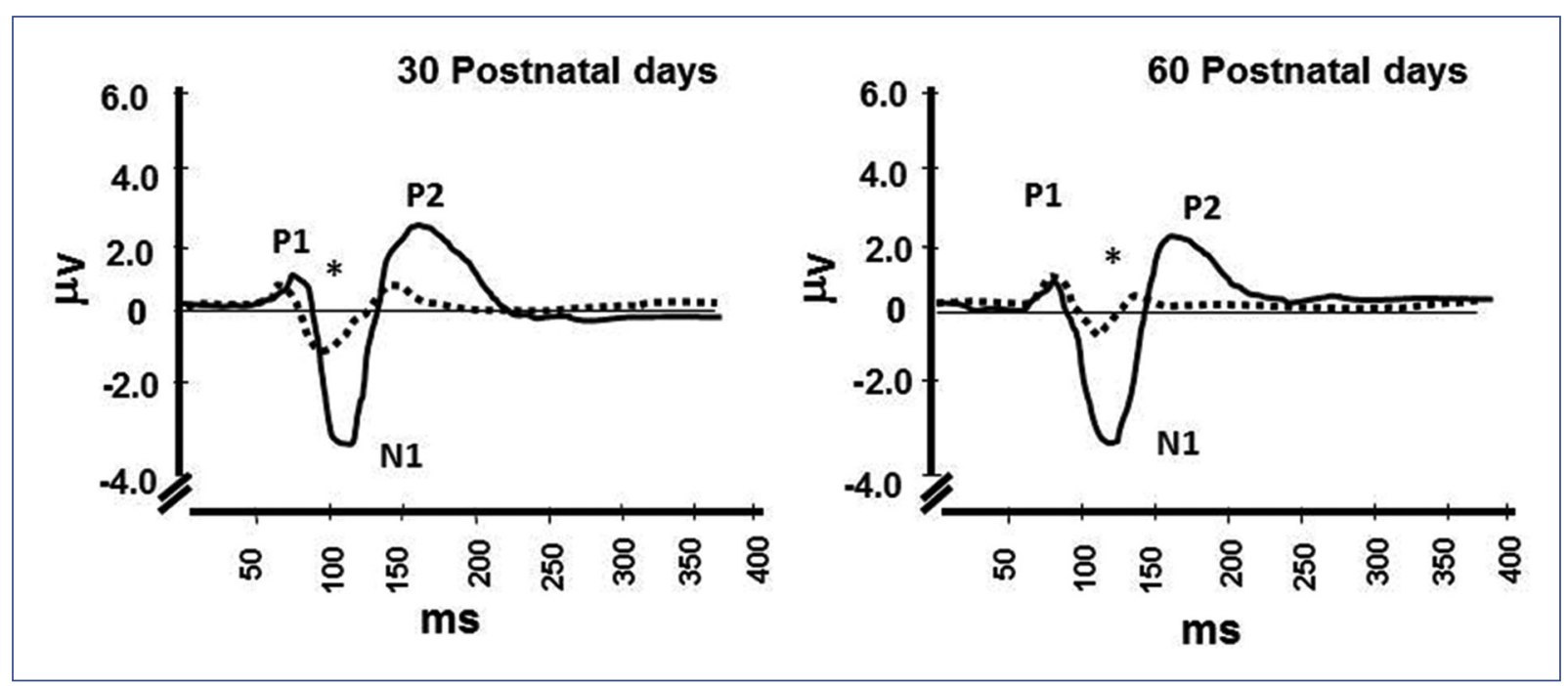

Figure 6. Auditory evoked potentials obtained from $\mathrm{Cz}$ reference electrode at a stimulation intensity of $60 \mathrm{~dB}$ in human controls (-) and infants with IUGR (---). Each recording represents the mean values from 12 and 13 infants in each group, respectively.

${ }^{*} p<0.001$. Wilcoxon test, comparing N1/P2 component amplitude of IUGR with controls ${ }^{47}$. IUGR, intrauterine growth restriction

serotonin-brain pathway could also result from intense early nutritional stress during the prenatal period and subsequent effects on the genetic regulatory system at transcriptional and posttranscriptional levels. Therefore, it appears that activation of the involved gene's systems could be related to the unexpected presence of an enzyme that has been reported to function only in peripheral tissues ${ }^{62-66}$, inducing the expression of different enzymatic isoforms that are generally not present in the brain, as is the case of TPH1 in IUGR subjects. Alternatively, nutritional stress could activate a separate isozyme with an antigenicity like the one of TPH1. This phenomenon has been observed with other metabolic pathways, in which their limiting control rate can be reached in a tissue-specific manner by an adaptive regulatory process of a system of two genes, each one encoding a specific isozyme. Also, mRNA expression may be modified under fasting and re-feeding conditions, and dietary limitation of any essential amino acid may initiate a signaling cascade leading to an increase in the translation of a "master regulator" activating transcription factor, leading to the regulation of the DNA-RNAprotein pathway ${ }^{88,89}$. The functional overactivation of the serotonergic neuronal system in some brain areas, such as the sensory cerebral cortices, increases its function during the perinatal and nursing periods. This effect lasts up to adulthood in rat brains ${ }^{73,74}$ and up to
3 months in the postnatal life of infants who underwent IUGR (measured through indirect methods), affecting mainly the sensory cortices' normal responses to specific stimuli46,47,51,52.

Given that 5-HT has an important morphogenetic function in the process of neurogenesis ${ }^{15,26,86,90-93}$ and other differentiating events such as synaptogenesis ${ }^{27,28,81}$, we can also propose that disturbances may originate harmful effects exerted by IUGR nutritional stress in the prenatal serotonin functions. We also observed significant alterations not only in brain serotonin metabolism but also in the process of corticogenesis, particularly in thalamocortical connectivity during somatosensory (S1) cortex formation, adding evidence on how changes produced by IUGR stress on fetal serotonergic function are reflected in morphogenetic processes, with an abnormal morphologic $\mathrm{S} 1$ development ${ }^{16,17}$.

By non-invasive methods, we detected sensory cortex responses directly associated with serotonergic regulation in infants: N1/P2 auditory intensity-dependent recordings. These recordings provide information on the auditory cortex's responses to specific stimuli. In our experience ${ }^{47}$ and that of Hegerl et al. ${ }^{94,95}$, an inverse correlation was found between the amplitude and intensity of the N1/P2 component of the auditory evoked potential response that the cortical serotonergic activity could produce on the auditory cortex (A1), rich in 5-HT innervation, regulating its responses to specific 
stimuli. Consequently, we obtained interesting and significant information on the sensory cortex function indicators and plasma biochemical indicators of brain-serotonin metabolism in IUGR infants. These parameters were markedly abnormal in IUGR rats and IUGR infants born from mothers diagnosed with placental insufficiency and, thus, malnourished ${ }^{45-47,49}$.

When allowed to NR, early undernourished subjects showed a good catch-up to normality on their physical parameters. However, functional and biochemical changes were not recoverable despite NR and remained up to adulthood in the rat brain compared to controls $\mathrm{s}^{70-74}$ and up to 3 months in infants ${ }^{52}$ (Table 1). This observation suggests the permanence of the alterations observed in the auditory cortex responses to specific stimuli, dramatically abnormal in infants who underwent prenatal stress with IUGR ${ }^{47}$ (Figure 6).

Another interesting question is why albumin capacity to bind L-Trp decreased significantly in IUGR patients' plasma. Plasma albumin from IUGR infants exhibited different binding properties than normal controls: a significantly higher $\mathrm{K}_{\mathrm{D}}$ and lower $\mathrm{B}_{\max }$, indicating a lower affinity for the ligand (L-Trp) and a lower number of binding sites ${ }^{52,96}$. This kinetic behavior could explain higher FFT levels in the plasma of IUGR malnourished individuals, leading to an imbalance between plasma-free L-Trp and other neutral amino acids and the L-Trp/neutral amino acid ratio favoring the $\mathrm{FFT}^{45,49}$. In turn, high levels of FFT are transported across the $\mathrm{BBB}$, activating the 5-HT biosynthetic pathway and, thus, reaching higher levels in the brainstem of IUGR individuals than controls. Unfortunately, there is no data on this binding phenomenon in humans, which possibly plays a relevant role in the serotonin metabolic pathway in the brain since FFT functions as a precursor for the synthesis of this brain neurotransmitter.

Authors who argue against albumin-L-Trp binding determinations have claimed that FFT is increased because plasma albumin concentration is decreased in malnourished individuals. However, in vitro binding experiments demonstrated that this is not the case because albumin concentration was the same, moleto-mole, in plasma derived from eutrophic control infants and derived from IUGR subjects and free of fatty acids (FFA). Therefore, under these assay conditions, differences in L-Trp binding kinetics are not dependent on differences in plasma albumin concentration. These differences would be present if binding experiments were performed directly on whole plasma albumin samples with no prior FFA. Undoubtedly, if the kinetics of albumin binding to L-Trp were measured directly, not only would its concentration be variable, but other factors would probably interfere ${ }^{52}$. Therefore, our findings suggest a possible structural difference in human IUGR albumin that allows this protein to change its conformation $^{97}$ in response to prenatal malnutrition stress. Thus, there is a different kinetic behavior for its binding to L-Trp in the plasma of human IUGR infants. In the context of serotonin metabolism in the brain, this phenomenon represents an essential peripheral regulatory mechanism for synthesizing this brain neurotransmitter, acting through the modulation of substrates for neurotransmitter synthesis. To our knowledge, this is the first time this has been described in newborns with IUGR and normal controls.

These findings support the notion that undernourishment distress during pre-, peri-, or postnatal development causes significant growth restriction and a possible change in TPH protein and plasma albumin structure, based on modifications in their kinetics and phosphorylation capacity ${ }^{52,59,60}$. Moreover, the decrease in TPH1-expressing serotonergic neurons coincides with a predominant enzyme expression compared with controls. A significant decrease of TPH2-immunoreactive neurons and a lower concentration of the enzyme suggest that stressful early conditions may induce epigenetic influences on the corresponding genes, as discussed previously, which shifts TPH expression toward TPH1 predominance, through a mechanism that, at present, is unclear, particularly concerning the presence of isoform 1 in controls.

Based on these results, it can be proposed that prenatal nutritional stress may significantly influence the brain's 5-HT biosynthetic pathway through mechanisms that may not necessarily be dependent on the genes encoding the enzymes but by epigenetic changes caused by intense nutritional stress and abnormal neurological changes induced by early undernourishment ${ }^{98-100}$. These remarkable enzymatic changes could be produced by modifications in the Pet-1 molecular apparatus, which appear to be essential in regulating enzyme expression in the serotonergic biosynthetic pathway from very early stages of brain development ${ }^{67-69,101}$. According to some authors, Pet-1 is also required to maintain TPH enzymes in the developing brain. Thus, significant alteration of the Pet-1-related molecular apparatus can be studied to gain further insight into the effects of early undernourishment on TPH enzymes activity in the developing brain. Another exciting possibility that would add information to this research project would be to establish the heritability of functional changes in tryptophan-5-hydroxylases 
and plasma albumin ${ }^{52,59,60,61}$ and their metabolic consequences on brain serotonin biosynthesis, which mainly affect the brain sensory function of IUGR infants. However, this phenomenon would be related to an epigenetic explanation.

In conclusion, our experimental data allowed extrapolation to human infants under similar pre-and perinatal developmental conditions. On this basis, the proposal of a psychopathological alteration of the brain-serotonin in these patients was supported, reinforced by the significant morphological, neurobiochemical, biochemical, and electrophysiological alterations affecting the serotonergic functions of the brain from the prenatal stage. These alterations could favor abnormal cognitive development or a predisposition to psychiatric abnormalities related to brain serotonergic function.

Experimental work continues in our group to obtain more information on this exciting and relevant topic.

\section{Ethical disclosures}

Protection of human and animal subjects. The authors declare that no experiments were performed on humans or animals for this study.

Confidentiality of data. The authors declare that they have followed the protocols of their work center on the publication of patient data.

Right to privacy and informed consent. The authors declare that no patient data appear in this article.

\section{Conflicts of interest}

The authors declare no conflict of interest.

\section{Funding}

This work was financially supported by the Mexican Institute of Social Security (Instituto Mexicano del Seguro Social, IMSS) (FIS/IMSS/PROT/G15/1404) and the Laboratory of Neuro-ontogeny at CINVESTAV-IPN, Mexico.

\section{Acknowledgments}

We would like to express here our fond memories of the Mexican Professionals who pioneered the renaissance of the Mexican Nutritional Sciences' School, including Joaquín Cravioto, Silvestre Frenk, Federico Gómez, and Rafael Ramos-Galván (in the period from 1940-1970) at the Hospital Infantil de México and
Hospital de Pediatría, Centro Médico Nacional Siglo XXI, Instituto Mexicano del Seguro Social, Mexico.

The authors acknowledge the valuable assistance provided by Dr. Ismael Rodríguez, Ignacio Vargas, José Carlos Guadarrama-Olmos, and Marisol BautistaTorres, and the excellent Experimental Animal Facilities of Unidad de Producción y Experimentación de Animales de Laboratorio (UPEAL), and Dr. Jorge Fernández-H of Centro de Investigación y de Estudios Avanzados del Instituto Politécnico Nacional, Mexico City. Also, the authors acknowledge the editorial support of Maggie Bruner.

\section{References}

1. Monk C, Georgieff MK, Osterholm EA. Research review: maternal prenatal distress and poor nutrition-mutually influencing risk factors affecting infant neurocognitive development. J Child Psychol Psychiatr. 2013;54:115-30

2. Gómez F, Ramos-Galván R, Cravioto J, Frenk S. Malnutrition in infancy and childhood, with special reference to Kwashiorkor. Adv Pediatr. 1955;7:131-69.

3. Cravioto J. Appraisal of the effect of nutrition on biochemical maturation. Am J Clin Nutr. 1962;11:484-92.

4. Malthus TR. An essay on the principle of population. In: Johnson J, publisher. London: Electronic Scholarly Publishing Project; 1998.

5. Zamenhof S, Van Marthens E. Brain Weight, Brain Chemical Content, And Their Early Manipulation. In: Hahn ME, Jensen C, Dudek BC, editors. Development and evolution of brain size. New York: Academic Press; 1979. pp. 164-85.

6. Rozovski SJ, Winick M. Nutrition and Cellular Growth. In: Winick M, editor. Human nutrition. A comprehensive treatise. Nutrition: pre-and postnatal development. New York: Plenum Press; 1979. pp. 61-102.

7. Rosso P, Cramoy C. Nutrition and Pregnancy. In: Winick M, editor. Nutrition, Pre- and Postnatal Development. New York: Plenum Press; 1979. pp. 133-228.

8. Zamenhof S, Van Marthens E. Nutritional Influences on Prenatal Brain Development. In: Gottlieb G, editor. Studies of the development of behavior and the nervous system: early influences. New York: Academic Press; 1978. pp. 149-86.

9. Chase HP, Welch NN, Dabiere CS, Vasan NS, Butterfield LJ. Alterations in human brain biochemistry following intrauterine growth retardation. Pediatrics. 1972;50:403-11

10. Ghittoni NE, Faryna de Raveglia I. Letters: Effects of malnutrition and subsequent rehabilitation on the lipid composition of cerebral cortex and cerebellum of the rat. J Neurochem. 1973;21:983-7.

11. Hurley LS. Developmental nutrition. Englewood Cliffs: Prentice-Hall; 1980.

12. Morgane PJ, Mokler DJ, Galler JR. Effects of prenatal protein malnutrition on the hippocampal formation. Neurosci Biobehav Rev. 2002;26:471-83.

13. Barros VG, Duhalde-Vega M, Caltana L, Brusco A, Antonelli MC. Astrocyte-neuron vulnerability to prenatal stress in the adult rat brain. J Neurosci Res. 2006:83:787-800

14. Lebrand C, Cases O, Adelbrecht C, Doye A, Álvarez C, El Mestikawy S, et al. Transient uptake and storage of serotonin in developing thalamic neurons. Neuron. 1996;17:823-35.

15. Levitt $P$, Harvey JA, Friedman E, Simansky K, Murphy EH. New evidence for neurotransmitter influences on brain development. Trends Neurosci. 1997;20:269-74.

16. Gutiérrez-Ospina G, Manjarrez-Gutiérrez G, González C, López S, Herrera R, Medina-Aguirre I, et al. Neither increased nor decreased availability of cortical serotonin (5HT) disturbs barrel field formation in isocaloric undernourished rat pups. Int J Dev Neurosci. 2002;20:497-501.

17. Medina-Aguirre I, Gutiérrez-Ospina G, Hernández-Rodríguez J, Boyzo A, Manjarrez-Gutiérrez G. Developmental of 5-HT1B, SERT and thalamo-cortical afferents in early nutritionally restricted rats: an emerging explanation for delayed barrel formation. Int J Dev Neurosci. 2008;26:225-31.

18. Dori I, Dinopoulos A, Blue ME, Parnavelas JG. Regional differences in the ontogeny of the serotonergic projection to the cerebral cortex. Exp Neurol. 1996;138:1-14

19. Jacobs BL, Azmitia EC. Structure and function of the brain serotonin system. Physiol Rev. 1992;72:165-229.

20. Steinbusch HW. Distribution of serotonin immunoreactivity in the central nervous system of the rat cell bodies and terminals. Neuroscience. 1981;6:557-618. 
21. Takahashi $\mathrm{H}$, Nakashima S, Ohama E, Takeda S, Ikuta F. Distribution of serotonin-containing cell bodies in the brainstem of the human fetus determined with immunohistochemistry using antiserotonin serum. Brain Dev. 1986:8:355-65.

22. Takeuchi $Y$, Kimura H, Matsuura T, Yonezawa T, Sano Y. Distribution of serotonergic neurons in the central nervous system. J Histochem Cytochem. 1983;31:181-5.

23. Choi DS, Kellerman O, Richard S, Colas JF, Bolaños-Jiménez F, Tournois $\mathrm{C}$, et al. Mouse $5-\mathrm{HT}_{2 \mathrm{~B}}$ receptor-mediated serotonin trophic functions. Ann NY Acad Sci. 1998;861:67-73.

24. Gromova HA, Chubakov AR, Chumasov El, Konovalov HV. Serotonin is a stimulator of hippocampal cell differentiation in tissue culture. Int J Dev Neurosci. 1983;1:339-49.

25. Haydon PG, McCobb DP, Kater SB. The regulation of neurite outgrowth growth cone motility, and electrical synaptogenesis by serotonin. J Neurobiol. 1987;18:197-215.

26. Lauder MJ, Krebs H. Serotonin as a differentiation signal in early neurogenesis. Dev Neurosci. 1978;1:15-30.

27. Mercado R, Hernández J. A molecular recognizing system of serotonin in rat fetal axonal growth cones: uptake and high-affinity binding. Brain Res Dev Brain Res.1992;69:133-7.

28. Mercado R, Floran B, Hernandez J. Regulated release of serotonin from axonal growth cones isolated from the fetal brain. Neurochem Int. 1998:32:103-6.

29. Whitaker-Azmitia PM. Serotonin and brain development: role in human developmental diseases. Brain Res Bull. 2001;56:479-85.

30. Fillion MP, Hernandez RJ, Bauguen C, Fillion G. Postnatal development of high-affinity neuronal recognition sites for $3 \mathrm{H}-5-\mathrm{HT}$ in rat brain. Dev Neurosci. 1982;5:484-91.

31. Nebigil CB, Etienne N, Schaerlinger B, Hickel P, Launay JM, Maroteaux L. Developmentally regulated serotonin 5-HT2B receptor. Int J Dev Neurosci. 2001;19:365-72.

32. Jouvet M. Sleep and serotonin: an unfinished story. Neuropsychopharmacology. 1999;21:24S-27S

33. Oscós A, Hernandez RJ. Gestational malnutrition and drugs affecting brain serotonin: effects on temporal control behavior. Behav Neural Biol. 1982;34:358-71.

34. Randic M, Yu HH. Effects of 5-hydroxytryptamine and bradykinin in cat dorsal horn neurons activated by noxious stimuli. Brain Res. 1976;111:197-203.

35. Shor-Posner G, Grinker JA, Marinescu C, Brown O, Leibowitz SF. Hypothalamic serotonin in the control of meal patterns and macronutrient selection. Brain Res Bull. 1986;17:663-71.

36. Díaz MA, Chagoya GG, Hernández-RJ. Modificación por desnutrición ontogénica de la neurotransmisión serotoninérgica cerebral y de una conducta relacionada. Bol Med Hosp Infant Mex. 1993;50:17-26.

37. Mann JJ. Role of the serotonergic system in the pathogenesis of major depression and suicidal behavior. Neuropsychopharmacology. 1999;21:99S-105S.

38. Andrade R. Regulation of membrane excitability in the central nervous system by serotonin receptor subtypes. Ann N Y Acad Sci. 1998;861:190-203.

39. Whitaker-Azmitia PM. Role of serotonin and other neurotransmitter receptors in brain development: basis for developmental pharmacology. Pharmacol Rev, 1991:43:553-61.

40. McMenamy RH, Oncley JL. The specific binding of L-tryptophan to serum albumin. J Biol Chem. 1958;233:1436-47.

41. Pardridge WM. Tryptophan transport through the blood-brain barrier: in vivo measurement of free and albumin-bound amino acid. Life Sci. 1979;25:1519-28

42. Yuwiler A, Oldendorf WH, Geller E, Braun L. Effects of albumin binding and amino acid competition on tryptophan uptake into the brain. J Neurochem. 1977;28:1015-23.

43. Boadle-Bider MC. Regulation of serotonin synthesis. Prog Biophys Mol Biol. 1993:60:1-15.

44. Manjarrez G, Chagoya G, Hernández J. Perinatal brain serotonin metabolism in rats malnourished in utero. Biol Neonate. 1988;54:232-40.

45. Hernández RJ, Manjarrez GG, Chagoya G. Newborn humans and rats malnourished in utero: free plasma L-tryptophan, neutral amino acids and brain serotonin synthesis. Brain Res. 1989;488:1-13.

46. Manjarrez G, Contreras JL, Chagoya G, Hernández-R J. Free tryptophan as indicator of brain serotonin synthesis in infants. Pediatr Neurol. 1998;18:57-62

47. Manjarrez G, Cisneros I, Herrera R, Vázquez F, Robles A, Hernández J. Prenatal impairment of brain serotonergic transmission in infants. J Pediatr. 2005; 147:592-6

48. Hernández RJ. Development pattern of the serotonin synthesizing enzyme in the brain of postnatally malnourished rats. Experientia. 1973;29:1487-8

49. Manjarrez GG, Chagoya GG, Hernández RJ. Desnutrición intrauterina I. L-triptófano, serotonina y aminoácidos plasmáticos en humanos. Bol Med Hosp Infant Mex. 1988;45:729-44.

50. Manjarrez GG, Chagoya GG, Hernández RJ. Desnutrición intrauterina: II. L-triptófano, triptófano-5-hidroxilasa y serotonina en el cerebro de rata. Bol Med Hosp Infant Mex. 1989;45:808-16.
51. Manjarrez GG, Contreras LJ, Magdaleno VM, Chagoya GG, Hernández RJ. Elevación de la fracción libre del L-tripófano plasmático en lactantes desnutridos in útero hasta el tercer mes de edad postnatal. Bol Med Hosp Infant Mex. 1997:54:12-9.

52. Hernández RJ, Meneses L, Herrera R, Manjarrez G. Another abnormal trait in the serotonin metabolism path in intrauterine growth-restricted infants. Neonatology. 2009:95:125-31.

53. Pérez-Cruet J, Tagliamonte A, Tagliamonte P, Gessa GL. Changes in brain serotonin metabolism associated with fasting and satiation in rats. Life Sci. 1972;11:31-9.

54. Miller M, Leahy JP, McConville F, Morgane PJ, Resnick O. Effects of developmental protein malnutrition on tryptophan utilization in brain and peripheral tissues. Brain Res Bull. 1977;2:347-53.

55. Lovenberg W, Weissbach $\mathrm{H}$, Udenfriend S. Aromatic L-amino acid decarboxylase. J Biol Chem. 1962;273:89-93.

56. Grahame-Smith DG. Tryptophan hydroxylation in brain. Biochem Biophys Res Commun. 1964;16:586-92.

57. Jequier E, Robinson DS, Lovenberg W, Sjoerdsma A. Further studies on tryptophan hydroxylase in rat brainstem and beef pineal. Biochem Pharmacol. 1969;18:1071-81.

58. Neckers LM, Biggio G, Moja E, Meek JL. Modulation of brain tryptophan hydroxylase activity by brain tryptophan content. J Pharmacol Exp Ther. 1977;201:110-6.

59. Manjarrez GG, Chagoya GG, Hernández RJ. Early nutritional changes modify the kinetics and phosphorylation capacity of tryptophan-5-hydroxylase. Int J Dev Neurosci. 1994;12:695-702.

60. Manjarrez GG, Chagoya GG, Hernández RJ. Cambios epigenéticos en la expresión de una proteína funcional en el cerebro inducidos por desnutrición gestacional. Bol Med Hosp Infant Mex. 1993;50:88-95.

61. Manjarrez GG, Martínez RK, Boyzo MA, Orozco SS, Hernández RJ. Increased expression of tryptophan-5-hydroxylase 1, but not 2, in brainstem as a result of intrauterine malnutrition. Int $\mathrm{J}$ Dev Neurosci. 2012;30:445-50

62. Veenstra-VanderWeele J, Cook EH Jr. Knockout mouse points to second form of tryptophan hydroxylase. Mol Intervent. 2003:3:72-5.

63. Walther DJ, Bader M. A unique central tryptophan hydroxylase isoform. Biochem Pharmacol. 2003;66:1673-80.

64. Walther DJ, Peter JU, Bashammakh S, Hörtnagl H, Voits M, Fink H, et al. Synthesis of serotonin by a second tryptophan hydroxylase isoform. Science. 2003;299:76

65. Zhang X, Beaulieu JM, Sotnikova TD, Gainetdinov RR, Caron MG. Tryptophan hydroxylase-2 controls brain serotonin synthesis. Science. 2004;305:217.

66. Zhang X, Beaulieu JM, Gainetdinov RR, Caron MG. Functional polymorphisms of the brain serotonin synthesizing enzyme tryptophan hydroxylase-2. Cell Mol Life Sci. 2006;63:6-11.

67. Liu C, Maejima T, Wyler SC, Casadesus G, Herlitze S, Deneris ES. Pet1 is required across different stages of life to regulate serotonergic function. Nat Neurosci. 2010;13:1190-8.

68. Hendricks T, Francis N, Fyodorov D, Deneris ES. The ETS domain factor Pet-1 is an early and precise marker of central serotonin neurons and interacts with a conserved element in serotonergic genes. J Neurosci. 1999;19:10348-56.

69. Hendricks TJ, Fyodorov DV, Wegman LJ, Lelutiu NB, Pehek EA, Yamamoto $B$, et al. Pet-1 ETS gene plays a critical role in 5-HT neuron development and is required for normal anxiety-like and aggressive behavior. Neuron. 2003:37:233-47.

70. Manjarrez GG, Magdaleno VM, Hernández RJ. Cambios inducidos por rehabilitación nutricional temprana en la vía serotoninérgica cerebral activada por desnutrición gestacional. Bol Med Hosp Infant Mex. 1995;52:69-76.

71. Manjarrez GG, Magdaleno VM, Chagoya G, Hernández RJ. Nutritional recovery does not reverse the activation of brain serotonin synthesis in the ontogenetically malnourished rat. Int J Dev Neurosci. 1996;14:641-8.

72. Manjarrez GG, Herrera MR, Hernández ZE Manuel AL, González RM, Hernández-RJ. Elevación crónica de la síntesis de serotonina cerebral en rata adulta desnutrida in útero y recuperada nutricionalmente durante el amamantamiento. Bol Med Hosp Infant Mex. 1998;55:651-8.

73. Manjarrez GG, Herrera MJ, González RM, Hernández ZE, Manuel AL, Hernández RJ. Long-term consequences of early undernourishment on the activation of brain serotonin synthesis in the rat: effect of nutritional recovery during the period of nursing. Nutr Neurosci. 1999:2:57-67.

74. Manjarrez GG, González RM, Boyzo MA, Herrera MR, Hernández RJ. Serotonin and dopamine in the hypothalamus of control and malnourished mother rats during pregnancy and lactation and body composition of their offspring. Nutr Neurosci. 2013;16:225-32.

75. Keller A, White EL, Cipolloni PB. The identification of thalamocortical axons terminals in barrels of mouse Sml cortex using immunohistochemistry of anterogradely transported lectin (Phaseolus vulgaris leucoagglutinin). Brain Res. 1985;343:159-65

76. Peat MA, Gibb JW. High-performance liquid chromatographic determination of indoleamines, dopamine, and norepinephrine in rat brain with fluorometric detection. Anal Biochem. 1983;128:275-80.

77. Johansen PA, Jennings I, Cotton RG, Kuhn DM. Tryptophan hydroxylase is phosphorylated by protein kinase A. J Neurochem. 1995;65:882-8. 
78. Naish JS, Boenisch T, Farmilo AJ, Stead RH. Handbook of Immunochemical Staining Methods. Carpinteria, CA: Dako Corp; 1989. pp. 1-41.

79. Lubchenco LO, Hansman C, Dressleer M, Boyd E. Intrauterine growth as estimated from liveborn birth-weight date at 24 to 42 weeks of gestation. Pediatrics. 1963;32:793-800.

80. Kramer MS, Oliver M, McLean FH, Dougherty GE, Willis DM, Usher RH. Determinants of fetal growth and body proportionality. Pediatrics. 1990;86:18-26.

81. Haydon PG, McCobb DP, Kater SB. Serotonin selectively inhibits growth cone motility and synaptogenesis of specific identified neurons. Science. 1984;226:561-4.

82. Lauder JM, Krebs $\mathrm{H}$. Effects of $\mathrm{p}$-chlorophenylalanine on time of neuronal origin during embryogenesis in the rat. Brain Res. 1976;107:638-44.

83. Chagoya G, Hernández RJ. L-tryptophan during gestation induces an increase in brain tryptophan-5-hydroxylase activity and serotonin synthesis. Proc West Pharmacol Soc. 1983;26:369-72.

84. Chanez C, Priam M, Flexor MA, Hamon M, Bourgoin S, Kordon C, et al Long-lasting effects of intrauterine growth retardation on 5-HT metabolism in the brain of developing rats. Brain Res. 1981;207:397-408.

85. Manjarrez G, Manuel AL, Mercado CR, Hernandez RJ. Serotonergic receptors in the brain of in utero undernourished rats. Int J Dev Neurosci. 2003;21:283-9.

86. de Oca ABM, Manjarrez GG, Hernández RJ. Molecular signaling of $5-\mathrm{HT} 1 \mathrm{~A}$ and presence serotonergic cells in the fetal cerebral cortex. World J Neurosci. 2013;3:76-82.

87. Manjarrez-Gutiérrez G, Hernández-Rodríguez J, Mondragón-Herrera JA Nutritional recovery and its effect on tryptophan-5-hydroxylases expression, cell number and on changes caused by intrauterine growth restriction in the developing brain. J Nutr Food Sci. 2020;10:774.

88. Kletzien RF, Harris PK, Foellmi LA. Glucose-6-phosphate dehydrogenase: a "housekeeping" enzyme subject to tissue-specific regulation by hormones, nutrients, and oxidant stress. FASEB J. 1994;8:174-81.

89. Givens RM, Lin MH, Taylor DJ, Mechold U, Berry JO, Hernández VJ. Inducible expression, enzymatic activity, and origin of higher plant homologs of bacterial RelA/SpoT stress proteins in Nicotiana tabacum. J Biol Chem. 2004;279:7495-504.
90. Bonnin A, Levitt P. Fetal, maternal, and placental sources of serotonin and new implications for developmental programming of the brain. Neuroscience. 2011;197:1-7.

91. Gaspar P, Cases O, Maroteaux L. The developmental role of serotonin: news from mouse molecular genetics. Nat Rev Neurosci. 2003;4:1002-12.

92. Vitalis T, Parnavelas JG. The role of serotonin in early cortical development. Dev. Neurosci. 2003;25:245-56.

93. Sodhi MS, Sanders-Bush E. Serotonin and brain development. Int Rev Neurobiol. 2004;59:111-74.

94. Hegerl U, Juckel G. Intensity dependence of auditory evoked potentials as an indicator of central serotonergic neurotransmission: a new hypothesis. Biol Psychiatry. 1993;33:173-87.

95. Hegerl U, Gallinat J, Mrowinski D. Intensity dependence of auditory evoked dipole source activity. Int J Psychophysiol. 1994;17:1-13.

96. Garber ZM. Las características de interacción y de unión con la albúmina en ratas normales y con desnutrición ontogénica [Tesis]. Ciudad de México: Universidad Iberoamericana; 1993.

97. Kragh-Hansen U. Structure and ligand binding properties of human serum albumin. Dan Med Bull. 1990;37:57-84.

98. Abumaria N, Rygula R, Havemann-Reinecke U, Rüther E, Bodemer W, Roos $C$, et al. Identification of genes regulated by chronic social stress in the rat dorsal raphe nucleus. Cell Mol Neurobiol. 2006;26:145-62.

99. Abumaria N, Rygula R, Hiemke C, Fuchs E, Havemann-Reinecke U, Rüther $\mathrm{E}$, et al. Effect of chronic citalopram on serotonin-related and stress-regulated genes in the dorsal raphe nucleus of the rat. Eur Neuropsychopharmacol. 2007;17:417-29.

100. Abumaria N, Ribic A, Anacker C, Fuchs E, Flügge G. Stress upregulates TPH1 but not TPH2 mRNA in the rat dorsal raphe nucleus: identification of two TPH2 mRNA splice variants. Cell Mol Neurobiol. 2008;28:331-42.

101. Pelosi B, Migliarini S, Pacini G, Pratelli M, Pasqualetti M. Generation of PET1210-Cre transgenic mouse line reveals non-serotonergic expression domains of PET-1 both in CNS and periphery. PLOS ONE. 2014;9:e104318. 